\title{
Pengendalian Internal, Love Of Money Terhadap Kecenderungan Kecurangan Akuntansi di BMT Kabupaten Kudus
}

\author{
Husnurrosyidah \\ Institut Agama Islam Negeri Kudus \\ husnurrosyidah@iainkudus.ac.id
}

\begin{abstract}
This study aims to determine the effect of internal control, love of money to the fraud accounting tendencies in the BMT at Kudus distric. This research is a quantitative approach used are primary data with survey methods through questionnaires. There are two independent variables in this study, namely (X1) internal control, and (X2) love of money. The dependent variable $(Y)$ in this study is the tendency of fraud accounting. The population in this study were all BMT employees in Kudus District who were members of the PBMT, totaling 302 employees. A sample of 173 respondents used the purposive sampling method. The results of this study indicate that: 1) internal control has a negative effect on the tendency of fraud accounting accounting to be indicated by the total effect of -0.66 and significant $(<0.01) .2)$ the morality of individuals influences the tendency of fraud accounting to be indicated by the total effect of 0.37 and significant $(<0.01)$.
\end{abstract}

Keywords: Internal control, love of money, fraud accounting tendencies.

\begin{abstract}
ABSTRAK
Penelitian ini bertujuan mengetahui pengaruh pengendalian internal, love of money terhadap kecenderungan kecurangan akuntansi di BMT kabupaten Kudus. Penelitian ini merupakan penelitian kuantitatif dengan data primer dan metode survei melalui penyebaran kuesioner. Variabel independen dalam penelitian ini yaitu $\left(\mathrm{X}_{1}\right)$ pengendalian internal, dan $\left(\mathrm{X}_{2}\right)$ love of money. Variabel dependen (Y) dalam penelitian ini adalah kecenderungan kecurangan akuntansi. Populasi dalam penelitian ini adalah seluruh karyawan BMT di Kabupaten Kudus yang tergabung dalam PBMT, sejumlah 302 karyawan. Sampel 173 responden dengan metode purposive sampling. Hasil penelitian menunjukkan: 1) pengendalian internal berpengaruh negatif terhadap kecenderungan kecurangan akuntansi sebesar -0.66 dan signifikan $(<0.01)$. 2) love of money berpengaruh positif terhadap kecenderungan kecurangan akuntansi sebesar 0.37 dan signifikan $(<0.01)$.
\end{abstract}

Kata kunci : Pengendalian internal, love of money, kecenderungan kecurangan akuntansi.

\section{PENDAHULUAN}

Masyarakat di berbagai lapisan di penjuru tanah air ini membutuhkan lembaga keuangan. Jenis lembaga keuangan yang dipercaya oleh masyarakat berdasarkan budaya serta kebiasaan masyarakat Indonesia. Masyarakat Indonesia merupakan populasi muslim terbesar di dunia, sehingga Indonesia membutuhkan lembaga keuangan yang bekerja sesuai dengan prinsip syariah. Lembaga keuangan syariah yang ditawarkan pada masyarakat Indonesia adalah BMT (Baitul Maal Wat Tamwil). Indonesia dengan populasi 
umat muslim terbesar, berpotensi mengembangkan BMT dan perbankan syariah. Adapun BMT dan perbankan syariah memiliki karakteristik masing-masing. Perbankan syariah memiliki keunggulan pada teknologi dan sistem perbankan yang sudah maju, sedangkan BMT memiliki keunggulan pendekatan humanis kepada para nasabah yang sebagian besar berasal dari kalangan pelaku ekonomi kelas menengah ke bawah. Teknologi dan sistem informasi yang terdapat pada BMT di Kudus tidak lebih canggih daropada yang dimiliki oleh bank syariah, sehingga kecurangan akuntansi terjadi di beberapa BMT di Kabupaten Kudus. Modus operandi dari kecurangan akuntansi di BMT diantaranya berupa fraud pada pinjaman (loan fraud). Loan Fraud merupakan bentuk kecurangan yang terjadi secara kolusi dari pihak internal maupun pihak eksternal. Kerugian yang disebabkan loan fraud ini sangat besar. Loan to non existent borrowers merupakan salah satu jenis loan fraud yang terjadi di lembaga keuangan. Loan fraud jenis ini memunculkan debitur fiktif maupun dengan cara debitur riil tetapi usaha debitur yang dibiayai tidak jelas atau tidak memenuhi syarat untuk diberikan pinjaman. Jenis loan debitur yang kedua adalah sham loan with kickbacks and divertion, pelaksanaan fraud ini dengan cara pinjaman fiktif atau pinjaman yang di fraud kan akan dijadikan sebagai bad debt. Loan with kickbacks and divertion, dapat juga dilakukan dengan melunasi pinjaman fiktif dari keuntungan pinjaman baru yang digelapkan (Priantara, 2013:165).

Fraud terjadi karena lemahnya pengendalian internal. Sistem Informasi Akuntansi pada lembaga keuangan termasuk dalam pengendalian internal. Ketika sistem informasinya baik, kinerja karyawan BMT juga meningkat. Sebaliknya, jika sistem informasi akuntansinya lemah, kinerja karyawannya juga buruk. Kinerja karyawan yang buruk mengakibatkan kinerja BMT menurun. Akibat dari penurunan kinerja tersebut maka BMT harus menanggung kerugian bahkan harus berhenti beroperasi (Husnurrosyidah, 2018).

Tahun 2016 terjadi fraud pada perbankan, yaitu Bank Tabungan Pensiunan Nasional (BTPN) Syariah dengan modus operandi membuat laporan keuangan dan data nasabah fiktif. Akibat tindakan fraud tersebut, BTPN Lampung mengalami kerugian sebesar Rp 169 juta. Tidakan fraud ini dilakukan oleh pihak internal, yaitu pegawai BTPN Syariah sendiri (Tribun Lampung, 2017). Beberapa kasus fraud pada dunia perbankan dengan implementasi digital banking juga sedang marak dilakukan pada saat ini. Modus yang sering digunakan adalah melakukan skimming dengan menggandakan pita magnetik 
dan phisiing dengan mengkloning dan memodifikasi website seolah seperti asli. Modus swim swap atau penggantian sim card yang dilakukan oleh pelaku bekerja sama dengan outlet seluler untuk bisa mendapakan akses terhadap sim card korban (Yudistira, 2017).

Fraud merupakan tindakan tidak wajar dan salah penyajian fakta atas penggunaan sumberdaya perusahaan secara disengaja untuk memperoleh keuntungan pribadi. Tindakan fraud merupakan perbuatan melawan hukum karena tidak sesuai dengan pasal 278 KUHP, pasal 268 KUHPer (Priantara, 2013:4). "Kecurangan akuntansi merupakan salah saji yang timbul dari kecurangan dalam pelaporan keuangan yaitu salah saji atau penghilangan secara sengaja jumlah atau pengungkapan dalam laporan keuangan untuk mengelabui pemakai laporan keuangan. Fraud juga diartikan sebagai salah saji yang timbul dari perlakuan tidak semestinya terhadap aktiva (seringkali disebut dengan penyalahgunaan atau penggelapan) yang berkaitan dengan pencurian aktiva entitas yang berakibat laporan keuangan tidak disajikan sesuai dengan Prinsip Akuntansi yang Berlaku Umum (PABU) di Indonesia (IAI, 2018:316)”.

Cressey menyatakan bahwa terdapat tiga kondisi yang umumnya hadir pada saat terjadinya fraud yaitu pressure (tekanan), opportunity (kesempatan) dan rationalization (pembenaran). Pressure (tekanan) muncul akibat kebutuhan atau masalah finansial, tetapi banyak yang terdorong akibat keserakahan. Keserakahan pada seseorang akan semakin meningkat jika orang tersebut memiliki moralitas yang rendah sehingga tidak dapat bertindak hal yang baik dan bermoral (Priantara, 2013:44).

Opportunity (kesempatan) merupakan peluang yang memungkinkan terjadinya fraud. Para pelaku fraud percaya bahwa aktivitas mereka tidak akan terdeteksi. Opportunity untuk melakukan fraud akan semakin kuat jika tingkat pengendalian internal dalam suatu organisasi rendah. Rationalization (pembenaran) terjadi karena seseorang mencari pembenaran atas aktivitasnya yang mengandung fraud. Para pelaku meyakini bahwa tindakannya merupakan tindakan yang wajar sebagai manusia yang memiliki sifat cinta uang (love of money), sehingga tindakannya itu tidak salah (Priantara, 2013:46-47).

Asimetri informasi mengakibatkan konflik antara principal dan agent. Pengendalian internal memegang peran penting dalam konflik tersebut. Pengendalian internal yang efektif akan meminimalisir terjadinya kecurangan (Jensen dan Meckling, 1976). Uang berhubungan dengan kepribadian individu dan merupakan variabel sikap. Cinta uang (love of money) adalah akar dari segala kejahatan (Tang dan Chiu, 2003). Seseorang melakukan kecurangan 
disebabkan adanya dorongan untuk mendapatkan sesuatu yang diinginkan. Salah satunya adanya kecintaan terhadap uang (love of money) (Tripermata et.al, 2016). Seseorang yang memiliki kecintaan terhadap uang lebih termotivasi untuk melakukan apapun demi memperoleh uang yang lebih banyak sekalipun melakukan tindakan yang tidak etis. (Tang dan Chiu, 2003).

Penelitian ini dilakukan pada BMT di Kabupaten Kudus dikarenakan BMT merupakan lembaga keuangan syariah yang memiliki pendekatan humanis dengan nasabah sehingga dekat dengan pelaku bisnis mikro. Namun, berdasarkan observasi beberapa BMT pernah mengalami kerugian diakibatkan adanya kecurangan akuntansi. Berdasarkan fenomena tersebut, maka penelitian ini bertema "Pengendalian Internal dan Love of Money Terhadap Kecenderungan Kecurangan Akuntansi di BMT Kabupaten Kudus".

Berdasarkan latar belakang tersebut, rumusan masalah penelitian ini adalah: (1) Bagaimana pengaruh antara pengendalian internal terhadap kecenderungan kecurangan akuntansi?; (2) Bagaimana pengaruh antara love of money terhadap kecenderungan kecurangan akuntansi?

\section{TINJAUAN PUSTAKA}

\section{Teori Agensi (Agency Theory)}

Hubungan keagenan adalah sebuah kontrak antara manajer (agent) dengan investor (principal). Terjadinya konflik kepentingan antara pemilik dan agen karena kemungkinan agen bertindak tidak sesuai dengan kepentingan principal, sehingga memicu biaya keagenan (agency cost). "Pemilik memiliki kepentingan agar dana yang telah diinvestasikannya memberikan pendapatan yang maksimal, sedangkan pihak manajemen memiliki kepentingan terhadap perolehan incentives atas pengelolaan dana pemilik perusahaan (Jensen dan Meckling, 1976)".

Konflik kepentingan ini akan menimbulkan biaya (cost) yang biasa disebut agency cost. Kinerja karyawan sangat berkaitan dengan bagaimana membuat para investor yakin bahwa manajer atau karyawan akan memberikan keuntungan bagi mereka, yakin karyawan tidak akan mencuri, memanipulasi laporan keuangan, menggelapkan atau menginvestasikan ke dalam proyek-proyek yang tidak menguntungkan berkaitan dengan dana yang telah ditanamkan oleh investor. Pengendalian internal merupakan mekanisme 
efektivitas yang mempunyai tujuan untuk meminimalisasi konflik keagenan. Pengawasan mekanisme pengendalian internal perusahaan yang baik, dianggap mampu mengurangi masalah keagenan. Maka dari itu, upaya perilaku oportunitas manajer dan kecenderungan untuk menyembunyikan informasi demi keuntungan pribadi dapat mengarah pada tingkat pengungkapan perusahaan. Dengan kata lain kinerja karyawan yang baik ditunjang dengan pengendalian internal yang efektif diharapkan akan dapat berfungsi untuk menekan biaya keagenan (agency cost) sehingga pada akhirnya dapat meningkatkan kinerja perusahaan dan tujuan perusahaan dapat dicapai.

\section{Pengendalian Internal}

Pengendalian internal dapat dilihat dari arti sempit dan arti luas. Arti sempit merupakan arti dari pengendalian internal yang dikenal sebagai intern check, yaitu pengecekan penjumlahan baik penjumlahan mendatar (cross footing) maupun penjumlahan menurun (footing) dilakukan oleh dua orang atau lebih yang bekerja secara independen dengan tujuan untuk memperoleh kebenaran angka. Arti luas pengendalian internal tidak hanya meliputi pengecekan penjumlahan, tetapi meliputi semua alat yang digunakan manajemen untuk mengadakan pengawasan.

Pengendalian internal dalam kerangka COSO adalah suatu "proses yang dipengaruhi oleh dewan direksi, manajemen dan karyawan lainnya dan didesain untuk memberikan keyakinan yang memadahi terkait pencapaian tujuan perusahaan (IAI, 2015:99)". "Proses yang dipengaruhi oleh dewan direksi, manajemen dan karyawan lainnya itu untuk memberikan keyakinan yang wajar sesuai dengan katagorinya yaitu efektifas dan efesiensi operasi, keandalan pelaporan keuangan, dan ketaatan dengan hukum dan aturan yang berlaku (Sawyer, 2005:144)".

\section{Komponen Pengendalian Internal Versi Commitee of Sponsoring Organization of}

\section{The Treadway Commision (COSO)}

COSO Internal Control Integrated Framework memiliki lima komponen utama yaitu: (1) Lingkungan Pengendalian (Control Environment); (2) Aktivitas Pengendalian (Control Activities); (3) Penilaian Risiko (Risk Assessment); (4) Informasi dan Komunikasi (Information and Communication); (5) Pemantauan (Monitoring). 
Pengendalian internal membuat manajemen bertanggung jawab menyiapkan laporan keuangan untuk kepentingan pihak intern dan ekstern perusahaan. Laporan yang disajikan harus dapat diandalkan. Selain itu, "Pengendalian Internal dimaksudkan agar organisasi melakukan kegiatannya sesuai dengan peraturan dan hukum yang berlaku (Mulyadi, 2013 : 234)".

\section{Cinta Uang (Love of money)}

Uang merupakan aspek yang sangat penting dalam kehidupan sehari-hari. (Rubenstein dalam Yeltsinta dan Fuad, 2013). Amerika Serikat mengukur keberhasilan dengan uang dan pendapatan. Meskipun uang tersebut digunakan secara universal, makna dan pentingnya uang tidak diterima secara universal (Harun, 2011). Herzberg mengatakan bahwa "uang adalah motivator bagi sebagian orang, tetapi orang lain menganggapnya sebagai higine factor (Yeltsinta dan Fuad, 2013)".

Konsep cinta uang (love of money) untuk literatur psikologis mengukur perasaan seseorang secara subjektif tentang uang. Love of money sebagai perilaku seseorang terhadap uang, pengertian seseorang terhadap uang, serta keinginan dan aspirasi seseorang terhadap uang. Love of money dapat juga diartikan sebagai level kecintaan seseorang terhadap uang, bagaimana mereka menganggap pentingnya uang bagi kehidupan mereka. "Sikap terhadap uang dipelajari melalui proses sosialisasi yang didirikan pada masa kanak-kanak dan dipelihara dalam kehidupan dewasa (Tang dan Chiu, 2003)".

Orang-orang dengan orientasi love of money yang tinggi memiliki kepuasan yang rendah dengan gaji. Mereka juga menyebutkan bahwa konsep love of money sangat terkait dengan konsep ketamakan dan akar dari kejahatan. "Orang-orang dengan perilaku cinta uang atau money ethic yang tinggi akan menempatkan kepentingan yang besar pada uang akan kurang etis dan sensitif daripada orang-orang dengan money ethic rendah (Basri, 2015)". "Sikap seseorang yang memiliki sifat cinta uang yang berlebih akan cenderung memandang uang sebagai suatu kebutuhan dan berambisi untuk memperolehnya dengan berbagai cara (Pradanti dan Prastiwi, 2014)".

Terdapat keterkaitan secara langsung antara hubungan love of money dengan perilaku tidak etis yaitu "semakin tinggi kecintaan terhadap uang akan berakibat seseorang mengesampingkan perilaku etisnya demi memperoleh uang yang ia cintai 
(Tang dan Chiu, 2003)". Mulyani (2015) mengatakan bahwa "kecintaan seseorang terhadap uang dapat mengakibatkan seseorang lupa diri dengan nilai-nilai etika dan moral yang diilikinya". "Ketika kecurangan merupakan salah satu langkah untuk memenuhi permintaan uang, seseorang akan merasionalisasi dan membenarkan ketidakjujuran mereka dengan mudah (Ariely dalam Yeltsinta dan Fuad, 2013)”. Oleh karena itu, seseorang yang memiliki kecintaan terhadap uang yang berlebihan dapat menyebabkan dirinya terjerumus pada tindakan-tindakan jahat dan menghalalkan segala cara untuk memenuhi kebutuhan uangnya.

"Money ethic scale (MES) menghasilkan enam faktor yang diidentifikasi meliputi good, evil, achievement, respect, budged dan freedom (Furnham dan Argyle, 2008)". Good adalah gagasan bahwa uang adalah "baik", yaitu sifat positif tentang uang. Evil merupakan sifat negatif tentang uang. Achievement yaitu uang melambangkan prestasi seseorang. Respect (Self-esteem) yaitu uang dapat membantu orang mendapatkan harga diri dan rasa hormat dari orang lain. Budget yaitu bagaimana orang menganggarkan uang mereka. Freedom (power) yaitu uang adalah kekuatan, dengan uang seseorang mampu memiliki otonomi, kebebasan dan keamanan, menjadi apa yang diinginkan dan mempengaruhi orang lain.

\section{Kecenderungan Kecurangan Akuntansi}

Fraud diterjemahkan sebagai praktik kecurangan dan fraud sering diartikan sebagai irregularity atau ketidakteraturan dan penyimpangan. Fraud dilakukan di berbagai organisasi, baik di lingkungan swasta maupun di sektor publik. Motifnya sama, yaitu sama-sama memperkaya diri sendiri/golongan dan modus operandinya sama, yaitu dengan melakukan cara-cara yang illegal (Priantara, 2013:44).

Association of Certified Fraud Examiners (ACFE) menyusun peta mengenai fraud. Peta ini berbentuk pohon dengan cabang dan ranting. Tiga cabang utama dari fraud tree adalah Corruption, Asset misappropriation dan fraudulent statement. Sedangkan Delf (2004) menambahkan tipologi fraud yaitu cybercrime. Ini jenis fraud yang paling canggih dan dilakukan oleh pihak yang mempunyai keahlian khusus yang tidak selalu dimiliki oleh pihak lain. "Cybercrime juga akan menjadi jenis fraud yang paling ditakuti di masa depan dimana teknologi berkembang dengan pesat dan canggih (Priantara, 2013:66)”. 
Fraud triangle theory merupakan suatu gagasan yang meneliti tentang penyebab terjadinya kecurangan. Gagasan ini pertama kali diciptakan oleh Cressey (1953) yang dinamakan fraud triangle atau segitiga kecurangan. "Fraud triangle terdiri dari tiga kondisiyang umumnya hadir pada saat fraud terjadi yaitu pressure, opportunity, dan rationalization (Priantara, 2013:44)".

\section{Indikator Pengukur Kecenderungan Kecurangan Akuntansi}

Instrumen yang digunakan untuk mengukur kecenderungan kecurangan akuntansi terdiri dari lima item pertanyaan yang dikembangkan oleh peneliti adalah sebagai berikut; (1) Kecenderungan untuk melakukan manipulasi, pemalsuan atau perubahan catatan akuntansi; (2) Kecenderungan untuk melakukan penyajian yang salah atau penghilangan peristiwa transaksi atau informasi yang signifikan atas laporan keuangan; (3) Kecenderungan untuk sengaja melakukan kesalahan penerapan prinsip akuntansi; (4) Kecenderungan untuk melakukan penyajian laporan keuangan yang salah akibat pencurian terhadap aktiva yang membuat entitas membayar barang/jasa yang tidak diterima (SPAP, seksi 316 IAPI, 2011).

Model penelitian dalam penelitian ini dapat dilihat pada gambar 1 sebagai berikut:

\section{Gambar 1 \\ Bagan Model Penelitian}

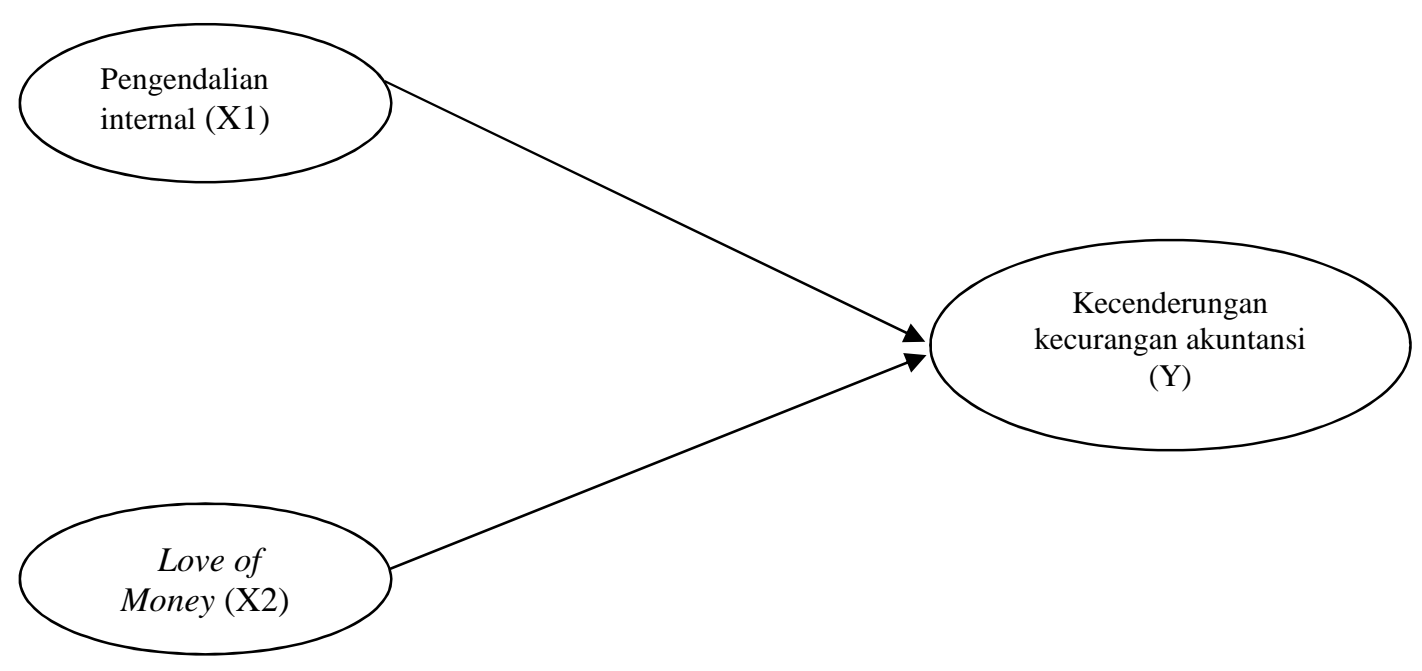

Berdasarkan bagan tersebut maka hipotesis dalam penelitian ini adalah sebagai berikut: 
$\mathrm{H}_{1}$ : Ada Pengaruh Antara Pengendalian Internal terhadap Kecenderungan Kecurangan Akuntansi pada BMT di Kabupaten Kudus.

$\mathrm{H}_{2}$ : Ada Pengaruh Antara Love of Money terhadap Kecenderungan Kecurangan Akuntansi pada BMT di Kabupaten Kudus.

\section{METODE PENELITIAN}

Penelitian ini merupakan penelitian lapangan (field research) dengan pendekatan kuantitatif. Data yang digunakan adalah data primer dengan metode survei melalui penyebaran kuesioner. Terdapat dua variabel independen dalam penelitian ini yaitu $\left(\mathrm{X}_{1}\right)$ pengendalian internal, dan $\left(\mathrm{X}_{2}\right)$ love of money. Variabel dependen $(\mathrm{Y})$ dalam penelitian ini adalah kecenderungan kecurangan akuntansi. Populasi dalam penelitian ini adalah seluruh karyawan BMT di Kabupaten Kudus yang tergabung dalam PBMT, sejumlah 302 karyawan. Sampel 173 responden dengan menggunakan metode purposive sampling. Teknik analisis data yang digunakan yaitu uji instrumen penelitian dan uji hipotesis. Metode statistik yang digunakan adalah teknik regresi.

\section{HASIL DAN PEMBAHASAN}

\section{Hasil Pengujian Validitas dan Reliabilitas Konstruk:}

Hasil pengujian outer/measurement model dengan menggunakan warp PLS diperoleh hasil sebagai berikut.

Tabel. 1

Outer/Measurement Model

\begin{tabular}{|l|c|c|c|}
\hline \multicolumn{1}{|c|}{ Konstruk } & AVE & $\begin{array}{c}\text { Composite } \\
\text { Reliability }\end{array}$ & $\begin{array}{c}\text { Cronbach } \\
\text { alpha }\end{array}$ \\
\hline 1. Pengendalian internal & 0.636 & 0.884 & 0.866 \\
\hline 2. Love of money & 0.578 & 0.807 & 0.721 \\
\hline $\begin{array}{l}\text { 3. Kecenderungan } \\
\text { kecurangan akuntansi }\end{array}$ & 0.549 & 0.915 & 0.894 \\
\hline
\end{tabular}

Sumber: Data primer 2019 yang diolah.

"Evaluasi validitas konvergen konstruk menggunakan indikator berupa loading factor dan average variance extracted (AVE) (Sholihin, Ratmono. 2013:73)". Hasil outer model dengan program warp PLS pada tabel 1 menunjukkan kriteria validitas konvergen telah terpenuhi yaitu loading lebih besar dari 0,60 dan AVE lebih besar dari 0,40. Hasil tersebut menunjukkan kriteria validitas diskriminan telah terpenuhi ditunjukkan dengan 
akar kuadrat AVE lebih besar daripada koefisien korelasi antar konstruk pada masingmasing kolom. Demikian juga reliabilitas telah terpenuhi dengan composite reliability dan cronbach alpha lebih besar dari 0,60.

\section{Validitas Diskriminan}

Hasil pengujian validitas diskriminan ditunjukkan pada tabel 2 sebagai berikut.

Tabel 2

Correlations among latent variables

\begin{tabular}{|c|c|c|c|}
\hline & PI & LOM & KKA \\
\hline PI & 0.580 & & \\
\hline LOM & 0.022 & 0.615 & \\
\hline KKA & 0.066 & 0.036 & 0.741 \\
\hline
\end{tabular}

Sumber: Data Primer 2019 yang diolah.

Matriks korelasi pada Tabel 2 menunjukkan kriteria validitas diskriminan telah terpenuhi ditunjukkan dengan akar kuadrat AVE lebih besar daripada koefisien korelasi antar konstruk pada masing-masing kolom. Hasil ini menunjukkan bahwa masing-masing indikator dari setiap variabel dapat mengukur variabel tersebut secara tepat daripada dengan variabel lain.

\section{Uji Goodness of Fit}

Tabel 3

Goodness Of Fit

\begin{tabular}{|c|c|c|c|}
\hline \multirow{2}{*}{ No } & \multirow{2}{*}{ Jalur } & \multicolumn{2}{|c|}{ total effect } \\
\cline { 3 - 4 } & & Koefesien & P-value \\
\hline 1 & APC & 0.986 & $<0.001$ \\
\hline 2 & ARS & 0.570 & $<0.001$ \\
\hline 3 & AVIF & 3.572 & $<5$ \\
\hline
\end{tabular}

Sumber: Data primer 2019 yang diolah.

Hasil estimasi model kriteria goodness of fit telah terpenuhi yaitu nilai APC dan ARS signifikan secara statistik dan AVIF kurang dari 5 (Sholihin dan Ratmono, 2013:61). Hal ini menunjukkan bahwa persyaratan untuk pengujian total effect terpenuhi. 


\section{Hasil Pengujian Total Effect}

\section{Gambar 2 \\ Total effect}

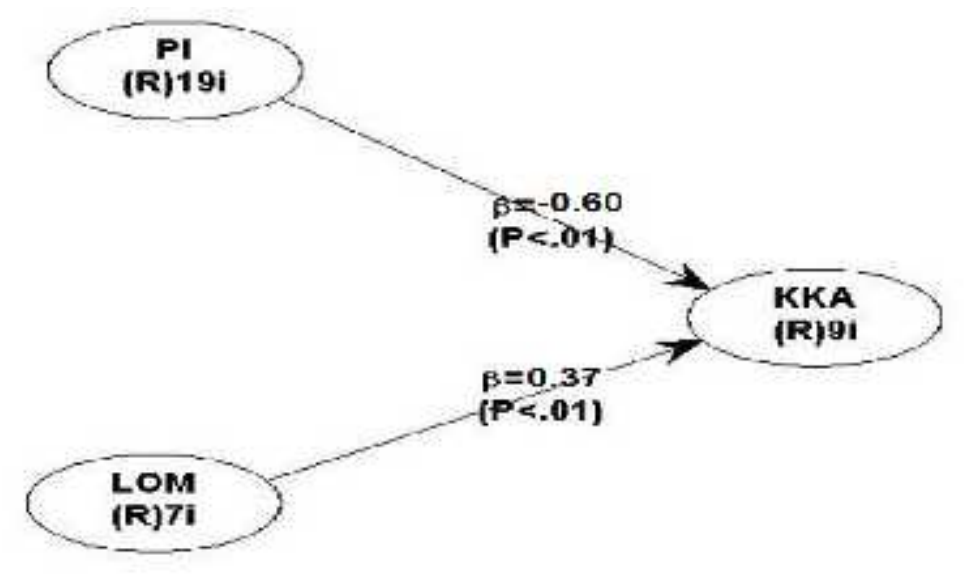

Berdasarkan hasil pengujian total effect dapat disimpulkan bahwa Pengendalian internal berpengaruh terhadap kecenderungan kecurangan akuntansi, dan love of money berpengaruh pada kecenderungan kecurangan akuntansi dengan signifikansi $\mathrm{P}<0.01$.

Tabel. 4

Hasil Pengujian total effect

\begin{tabular}{|c|c|c|c|}
\hline \multirow{2}{*}{ No } & \multirow{2}{*}{ Jalur } & \multicolumn{2}{|c|}{ total effect } \\
\cline { 2 - 4 } & & Koefesien & P-value \\
\hline 1 & PI $\rightarrow$ KKA & -0.60 & $<0.01$ \\
\hline 2 & LOM $\rightarrow$ KKA & 0.37 & $<0.01$ \\
\hline
\end{tabular}

Sumber: Data primer 2019 yang diolah.

Berdasarkan tabel tersebut, dapat diketahui sebagai berikut:

1. Hasil pengujian menunjukkan bahwa koefisien total effect pengendalian internal terhadap kecenderungan kecurangan akuntansi adalah sebesar -0.60 dan signifikan. Hal ini menunjukkan bahwa pengendalian internal berpengaruh terhadap kecenderungan kecurangan akuntansi.

2. Hasil pengujian menunjukkan bahwa koefisien total effect pengendalian internal terhadap kecenderungan kecurangan akuntansi adalah sebesar 0.37 dan signifikan. Hal ini menunjukkan bahwa love of money berpengaruh terhadap kecenderungan kecurangan akuntansi. 


\section{Hasil Pengujian Hipotesis}

Berdasarkan pengujian analisis jalur untuk masing-masing variabel yaitu : pengendalian internal, love of money dan kecenderungan kecurangan akuntansi sebagai berikut :

\section{1. $H_{1}$ : Ada pengaruh antara pengendalian internal terhadap kecenderungan}

\section{kecurangan akuntansi}

Hasil pengujian menunjukkan bahwa koefisien total effect pengendalian internal terhadap kecenderungan kecurangan akuntansi sebesar -0.60 dan signifikan $(<0.01)$. Hal ini menunjukkan bahwa $\left(\mathrm{H}_{1}\right)$ diterima yaitu ada pengaruh antara pengendalian internal terhadap kecenderungan kecurangan akuntansi.

\section{2. $\mathrm{H}_{2}$ : Ada pengaruh antara love of money terhadap kecenderungan kecurangan} akuntansi

Hasil pengujian menunjukkan bahwa koefisien total effect love of money terhadap kecenderungan kecurangan akuntansi sebesar 0.37 dan signifikan $(<0.01)$. Hal ini menunjukkan bahwa $\left(\mathrm{H}_{2}\right)$ diterima yaitu ada pengaruh antara love of money terhadap kecenderungan kecurangan akuntansi.

\section{PEMBAHASAN}

\section{Pengaruh Antara Pengendalian Internal Terhadap Kecenderungan Kecurangan}

\section{Akuntansi}

Hasil pengujian menunjukkan bahwa pengendalian internal berpengaruh negatif terhadap kecenderungan kecurangan akuntansi di BMT sekabupaten Kudus. Hal ini semakin efektif pengendalian internal dalam BMT, maka akan semakin rendah kecenderungan kecurangan akuntansi. Pengendalian internal dalam kerangka COSO merupakan suatu proses yang dipengaruhi oleh dewan direksi, manajemen dan karyawan lainnya yang didesain untuk memberikan keyakinan yang memadahi terkait pencapaian tujuan perusahaan (IAI, 2015: 99).

Pengendalian internal pada BMT merupakan sistem yang terdiri dari kebijakan-kebijakan dan prosedur-prosedur yang spesifik untuk mengelola BMT yang harus dipatuhi oleh setiap karyawan. Terdapat tujuan yang ditetapkan terlebih dahulu dalam pengendalian internal pada setiap BMT sehingga setiap hal yang dilakukan 
karyawan dan sesuai dengan pengendalian internal akan berakibat pencapaian tujuan BMT.

Pengendalian internal dijalankan oleh setiap karyawan BMT, bukan hanya pedoman, prosedur dan kebijakan perusahaan saja, sehingga pengendalian internal diharapkan mampu memberikan keyakinan yang memadai,bukan keyakinan yang mutlak bagi manajemen BMT sekabupaten Kudus. Maka dapat dinyatakan bahwa semakin efektif pengendalian internal pada BMT sekabupaten Kudus mengakibatkan semakin rendahnya tingkat kecenderungan kecurangan akuntansi yang dilakukan oleh karyawan BMT sekabupaten Kudus. Hal ini dikarenakan Pengendalian Internal membuat manajemen BMT bertanggung jawab menyiapkan laporan keuangan yang dapat diandalkan, serta pengendalian internal pada BMT juga dimaksudkan agar pihak manajemen melakukan kegiatannya sesuai dengan peraturan dan hukum yang berlaku.

Hasil penelitian ini konsisten dengan penelitian Eliza yang menyatakan bahwa sistem pengendalian intern berpengaruh negatif dan signifikan terhadap tingkat kecurangan akuntansi SKPD kota Padang. Ditunjukkan dari hasil uji hipotesis secara individu yaitu sistem pengendalian internal memiliki tingkat signifikan 0,011 <0,05 Maka hipotesis diterima (Eliza, 2015). Konsisten juga dengan penelitian yang telah dilakukan oleh Udayani "Pengaruh Pengendalian Internal dan Moralitas Individu Terhadap Kecenderungan Kecurangan Akuntansi di Villa kawasan Umalas”. Menyatakan bahwa pengendalian internal berpengaruh negatif dan signifikan terhadap kecenderungan kecurangan akuntansi dengan taraf nilai t hitung pada variabel pengendalian internal adalah sebesar -1.836 dengan tingkat signifikansi 0,040. Dengan menggunakan batas signifikansi 0,05 maka signifikansi tersebut dibawah taraf 5 persen yang artinya $\mathrm{H}_{0}$ ditolak dan $\mathrm{H}_{1}$ diterima. Hal ini menunjukan bahwa Pengendalian Internal berpengaruh negatif pada Kecenderungan Kecurangan Akuntansi (Udayani, 2017).

\section{Pengaruh Antara Love Of Money Terhadap Kecenderungan Kecurangan Akuntansi}

Hasil pengujian menunjukkan bahwa love of money berpengaruh terhadap kecenderungan kecurangan akuntansi di BMT sekabupaten Kudus. Hal ini semakin tinggi sifat love of money dalam diri karyawan BMT sekabupaten Kudus, maka akan semakin tinggi tingkat kecenderungan kecurangan akuntansi. "Love of money sebagai perilaku seseorang terhadap uang, pengertian seseorang terhadap uang, serta keinginan dan 
aspirasi seseorang terhadap uang (Tang et.al, 2003)". Terdapat keterkaitan antara love of money dengan kecenderungan kecurangan akuntansi yaitu ketika kecurangan merupakan salah satu langkah untuk memenuhi permintaan uang, orang cenderung untuk merasionalisasi dan membenarkan ketidakjujuran mereka dengan mudah. Oleh karena itu, seseorang yang memiliki kecintaan uang yang berlebih dapat menyebabkan dirinya terjerumus pada tindakan-tindakan jahat dan menghalalkan segala cara untuk memenuhi kebutuhan uangnya.

Hasil penelitian ini konsisten dengan penelitian yang dilakukan oleh Basri yang menyatakan bahwa Semakin tinggi sifat love of money seseorang maka persepsi etika penggelapan pajak juga semakin tinggi, dengan uji statistik t-statistik $1.7>1.6$ (onetailed). Hal ini berarti "seseorang yang memiliki sikap money ethic yang tinggi cenderung untuk melakukan penggelapan pajak, karena dianggap melakukan penggelapan pajak itu etis (Basri, 2017)". Implikasi dari penelitian ini adalah semakin tinggi sikap love of money seorang karyawan BMT, maka semakin tinggi kecenderungan untuk melakukan kecurangan akuntansi. karyawan hanya berfikir bagaimana cara mendapatkan banyak uang untuk memenuhi kepentingan pribadinya, tanpa memikirkan kerugian yang akan dialami oleh BMT. Love of money akan meningkatkan kecenderungan kecurangan akuntansi karena orang yang cinta pada uang akan menghalalkan segala cara untuk memperoleh uang walaupun dengan cara curang termasuk melemahkan sistem pengendalian internal yang ada di instansi tempat karyawan bekerja (Novikasari et.al, 2017).

\section{SIMPULAN}

Berdasarkan hasil penelitian diperoleh simpulan, antara lain:

1. Pengendalian internal berpengaruh negatif terhadap kecenderungan kecurangan akuntansi pada BMT di Kabupaten Kudus. Ditunjukkan dengan hasil pengujian koefisien total effect pengendalian internal terhadap kecenderungan kecurangan akuntansi sebesar -0.66 dan signifikan $(<0.01)$. Hal ini berarti semakin efektif pengendalian internal pada BMT, maka semakin rendah kecenderungan kecurangan akuntansi. Penelitian ini konsisten dengan hasil penelitian yang telah dilakukan oleh Eliza (2015), penelitian yang dilakukan Novikasari et.al (2017) dan Udayani et.al (2017). 
Pengendalian Internal, Love .... (Husnurrosyidah) $P-I S S N$ : $2502-9304$ E-ISSN : $\underline{2581-2157}$

2. Love of money berpengaruh terhadap kecenderungan kecurangan akuntansi pada BMT di Kabupaten Kudus. Ditunjukkan dengan hasil pengujian koefisien indirect effect love of money terhadap kecenderungan kecurangan akuntansi (jalur b) pada model (2) sebesar 0.07 dan signifikan (0.01). Hal ini berarti semakin tinggi love of money pada karyawan BMT, maka semakin tinggi kecenderungan kecurangan akuntansi. Penelitian ini konsisten dengan hasil penelitian yang telah dilakukan oleh Tripermata (2016).

\section{DAFTAR PUSTAKA}

Basri, Yesi Mutia. (2015). "Pengaruh Gender, Religiusitas dan Sikap Love of money pada Persepsi Etika Penggelapan Pajak Mahasiswa Akuntansi." Jurnal Ilmiah Akuntansi dan Bisnis. Vol 10 No 1 Januari 2015

Budiningsih, Asri. (2004). Belajar dan Pembelajaran. Yogyakarta : Rineka Cipta.

Bulutoding, Lince. Rika Paramitasari, Dwi Ayu dan Harun, Ferawati. (2017). "Pengaruh Sikap Machiavellian dan Love of money Terhadap Perilaku Etis Auditor.” Jurnal Ilmiah Akuntansi Peradaban. Vol 3 No 2 Desember 2017.

Cohen, J.R, Pant, L.W dan Sharp, D. (2001). “An Examination of the Differences in Ethical Decision-Making Between Canadian Business Students And Accounting Profesionals". Journal of Business Ethic.

Eisenhardt, Kathleem. (1989). Agency Theory: An Assesment and Review. Academy of Management Review. 13(1), pp: 57-74.

Eliza, Yuliana. (2015). ” Pengaruh Moralitas Individu dan Sistem Pengendalian internal terhadap kecenderungan kecurangan akuntansi” Jurnal Akuntansi Vol 4 No 1 Oktober 2015.

Ferdinand, Augusty. (2006). Metode Penelitian Manajemen. Semarang: BPFE Universitas Diponegoro.

Furnham, Ardian dan Argyle, Michael. (2008). The Psikology Of Money. Roudletge. London.

Husnurrosyidah. (2018). "Pengaruh Pelatihan Akuntansi Syariah, Sistem Informasi Akuntansi dan Pengendalian Internal Terhadap Kinerja Karyawan di BMT Kabupaten Kudus”. Jurnal Equilibrium Vol 6 No 2 Tahun 2018. 
Ikatan Akuntan Indonesia. (2015). Modul Chartered Accountant: Sistem Informasi dan Pengendalian Internal. Jakarta : IAI.

Ikatan Akuntan Indonesia. (2018). Standar Akuntansi Keuangan. Pernyataan Standar Akuntansi Keuangan nomor 1.

Ikatan Akuntan Publik Indonesia. (2011). Standar Profesional Akuntan Publik. SA Seksi 319. Pertimbangan Atas Pengendalian Intern Dalam Audit Laporan Keuangan.

Jensen \& Meckling. (1976). "The Theory of The Firm: Manajerial Behavior, Agency Cost, and Ownership Structure" . Journal of Financial and Economics3(1), pp: 305360.

Mulyadi. (2013). Sistem Akuntansi. Edisi Ketiga. Cetakan Ketiga. Jakarta: Salemba Empat.

Mulyani, Sri. (2015). “Analisis Pengaruh Jenis Kelamin dan Status Pekerjaan terhadap Persepsi Etis Mahasiswa Akuntansi dengan Love of Money sebagai Variabel Intervening". Majalah Ilmiah Solusi. 14(3): 1-15.

Novikasari, Yully. Desmiyawati, dan Silvi, Alfiati. (2017). "Pengaruh Moralitas Individu, Sistem Pengendalian intern Pemerintah dan Ketaatan Aturan Akuntansi terhadap kecenderungan kecurangan akuntansi” JOM Fekon Vol 4 No 1 Februari 2017.

Pradanti, Noviani Rindar dan Prastiwi, Andri. (2014). “Analisis Pengaruh Love of money Terhadap Persepsi Etis Mahasiswa Akuntansi." Diponegoro Journal Of Accounting. Vol 3 No 32014.

Priantara, Diaz. (2013). Fraud Auditing dan Investigation. Jakarta: Mitra Wacana Media. Priantara, Diaz. (2017). "Ketika Skandal Fraud Akuntansi Menerpa British Telecom dan PwC" Warta Ekonomi. Diakses pada : 5 November 2018. https://www.wartaekonomi.co.id/read145257/ketika-skandal-fraud-akuntansimenerpa-british-telecom-dan-pwc.html

Rindayanti dan Budiarto, Dekeng Setyo. (2017). "Hubungan antara love of money, Machiavellian dengan persepsi etis: Analisis berdasarkan perspektif gender" Akuntabilitas: Jurnal Ilmu Akuntansi. Vol 10 No 2 Oktober 2017.

Sawyer, Dittenhofer, S. Cheiner. (2005). Internal Auditing. Buku Satu. Edisi Kelima. Jakarta : Salemba Empat.

Sholihin, Mahfud. Ratmono, Dwi. (2013). Analisis SEM-PLS dengan warp pls 3.0 untuk hubungan non linier dalam penelitian sosial dan bisnis. Yogyakarta: Andi. 
Silvesterstone, Howard and Michael Sheetz. (2007). "Forensic Accounting and Fraud Auditing for Non-Exsperts". USA 2007.

Sugiyono. (2009). Metode Pelitian Bisnis. Cetakan ke-14. Bandung: Alfabeta.

Supomo, Bambang. Indrianto, Nur. (2012). Metodologi Penelitian Bisnis untuk Akuntansi dan Manajemen. FE UGM: Yogyakarta.

Tang, T.L.P dan Chiu, R.K. 2003. "Income Money Ethic, Pay Satisfaction, Commitment, And UnethicalBehaviour: Is the love of money the root of evil from Hongkong emplooyees?" J ournal of business ethics, 46, 13-30.

Tripermata, Lukita. Sari, Diah Manda dan Gustini, Emilia. (2016). "Pengaruh Struktur Modal dan Kinerja Keuangan Terhadap Nilai Perusahaan Perbankan di Bursa Efek Indonesia” Jurnal Ilmiah Ekonomi Global Masa Kini Vol 7 No 3 Desember 2016.

Udayani, Anak Agung K Finty dan Sari, Maria M. Ratna. (2017). "Pengaruh Pengendalian internal dan Moralitas Individu terhadap kecenderungan kecurangan akuntansi” E-Jurnal Akuntansi Universitas Udayana Vol. 18.3. Maret 2017.

Wilopo. (2006). Analisis Faktor-Faktor Yang Berpengaruh Terhadap Kecenderungan Kecurangan Akuntansi Studi Pada Perusahaan Publik dan Perusahaan Badan Usaha Milik Negara. SNA IX : Padang.

Yelsinta, Ratih dan Fuad. (2013). “Love of money, Pertimbangan Etis, Machiavellianisme, Questionable Action: Implikasi Pengambilan Keputusan Etis Mahasiswa Akuntansi denga Variabel Moderasi Gender". Disertasi tidak dipublikasikan. Universitas Diponegoro.

Yudistira, Galvan. (2017). “Bank BUMN Ungkap Modus Baru Perbankan”. Kontan.co.id. https://keuangan.kontan.co.id/news/bank-bumn-ungkap-modus-baru-fraudperbankan. Diakses pada 20 Januari 2019 pukul; 16.54. 